\title{
Editorial
}

\section{A polaridade orador - auditório}

Marco Antonio Guimarães da Silva,Med.Dr.Sci.

marco@atlanticaedu.com.br

Há muitos anos atrás, participava como expectador de uma conferência em um congresso de medicina e, durante a sessão de perguntas, contestei uma idéia defendida pelo médico conferencista. Havia vivenciado uma situação na pesquisa que fizera, e essa vivência me serviu de substrato para iniciar uma discussão, a qual acabou por envolver quase que toda a platéia, constituída essencialmente por médicos. Minha argumentação acabou por angariar partidários, gerando um certo desconforto entre orador e auditório. Passado o episódio, fiquei com a impressão, sem maiores reflexóes, de que aquela confusão entre conferencista e ouvintes havia transformado aquele congresso no mais interessante evento que participei em toda a minha vida acadêmica.

Ao saber que o próximo Congresso Brasileiro de Fisioterapia será organizado na cidade de Rio de Janeiro, volto ao tema, fazendo uma nova leitura da relação orador-auditório, na tentativa de melhor entender o fato ocorrido há 30 anos atrás.

O episódio em si envolveu questôes relacionadas a experiências que vivi antes do congresso médico. Tais experiências ampararam minha retórica, o que acabou por gerar uma grande polaridade entre orador e auditório.

Quando Hegel e Heidegger dizem que "A coerência verbal de nossas verdades físicas e metafísicas só se conhece retrospectivamente", nos fornecem a chave para entendermos o papel que as experiências vividas no passado exercem nesse processo. Ao discutir, com o conferencista, situaçóes que poderiam ocorrer, prospectivamente, o que eu dizia desse futuro era o produto de uma síntese pessoal apoiada na minha experiência investigatória.

A forma como argumentei, os motivos utilizados para explicar os resultados obtidos e a busca de adesão à reprodução de resultados futuros constituíram minha retórica.

Uma retórica pode ser feita por persuasáo ou por convencimento. Para os que desejarem aprofundar o tema, sugiro ler Aristóteles (A Retórica). Ao centrarmos força nos resultados, nosso discurso argumentativo volta-se para a adesão pela persuasão. Quando nos esforçamos por apresentar razóes para os resultados que encontramos, nosso discurso argumentativo está a sugerir uma adesão por convencimento.

No caso do médico, a sua exposição estava fundamentada na argumentação pelos resultados, portanto, pela persuasáo, sem se preocupar em explicar algumas razôes que invalidavam a teoria que ele entáo apresentava.

Se por um lado o conferencista não foi muito feliz em refutar os argumentos da platéia, há que se reconhecer que a ampla discussão, permitida por ele, sobre o tema, com envolvimento de quase toda a platéia, foi bastante louvável. 
$\mathrm{O}$ auditório não pode ser encarado como uma comunidade onde o conhecimento deva ser imposto. A polaridade orador-auditório deve ser flexível e apresentar-se como uma seqüência dinâmica de posiçóes de orador e de posiçóes de auditório, intercambiáveis e mútuas, que tornem o resultado do intercâmbio inacabado. Em algumas situações, o orador pode se transformar em auditório e vice-versa. A direção do convencimento pode se inverter e partir do auditório para o orador com um contingente reversível
Esperemos que o espírito dos congressistas que virão ao Rio de Janeiro para o Congresso Brasileiro de Fisioterapia, sejam eles auditório ou oradores, esteja aberto à visão que defendi e reproduzam suas trajetórias e experiências de conhecimento dentro de uma ótica intercambiável.

No mais, gostaríamos de expressar nosso contentamento por saber que a presidente do congresso e o presidente da comissão cientifica são nossos editores associados. 